\title{
The Perception of Malaysian ESL Tertiary Level Students on the IELTS Test
}

\author{
Dhiya Amalina Zahari ${ }^{1}$ \\ Jeremiah Dhayaalan Jackson \\ Dhayaalan $^{2}$

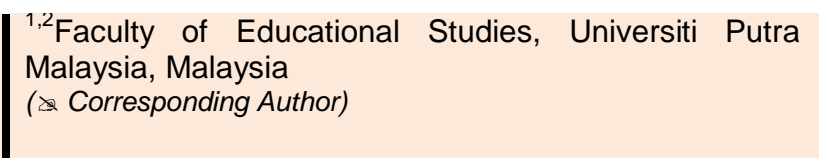

\begin{abstract}
Currently, the most acknowledged test to qualify for overseas universities is the IELTS test which is referred to as the International English Language Testing System. It is implemented as an accreditation tool and is believed to be a reputable and trustworthy tool of language competence by tertiary institutions which employ its use. Regardless of the current attention received by IELTS today, the views and opinions of candidates sitting for the test have seldom been looked into. Thus, this research is focused on examining the perception of Kolej MARA Banting candidates on the IELTS test. Consequently, a 9 item questionnaire on perception was given to 20 participants prior to and after sitting for the IELTS test. The data gathered was evaluated using t- test analysis to investigate the comparative differences among the learners' perception prior to and after sitting for the test. Results proclaimed that candidates obtained a notably more positive perception after the test. Hence, some implications are made for all stakeholders especially those learners who are planning to take the test, educational organizations that are overseeing IELTS preparatory programs, educators who aspire to train candidates in such programs and administers of the test.
\end{abstract}

Keywords: Attitude, Perception, Beliefs, IELTS, Tertiary education.

\section{Contents}

1. Introduction...

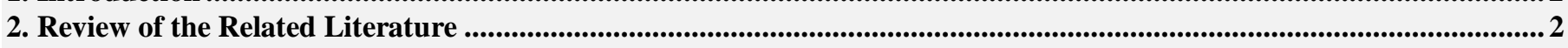

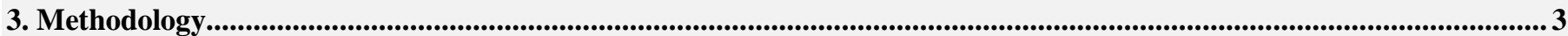

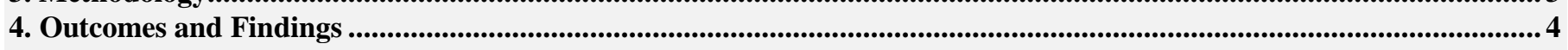

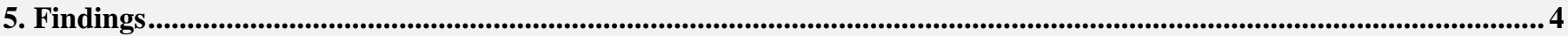

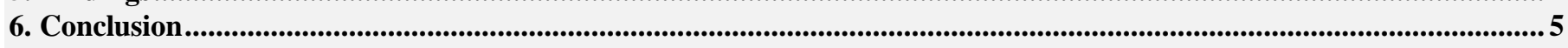

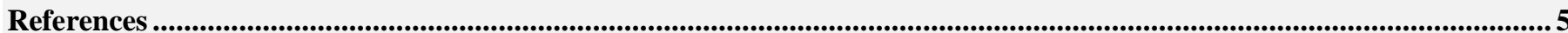

Citation | Dhiya Amalina Zahari; Jeremiah Dhayaalan Jackson Dhayaalan (2016). The Perception of Malaysian ESL Tertiary Level Students on the IELTS Test. Asian Journal of Education and Training, 2(1): 1-6.

DOI:

Licensed:

10.20448/journal.522/2016.2.1/522.1.1.6 Crossref

Contribution/Acknowledgement: All authors contributed to the conception and design of the study.

Funding:

This work is licensed under a

Competing Interests:

Transparency:

This study received no specific financial support.

The authors declare that they have no conflict of interests.

The authors confirm that the manuscript is an honest, accurate, and transparent account of the study was reported; that no vital features of the study have been omitted; and that any discrepancies from the study as planned have been

History:

Ethical:

Publisher: explained.

Received: 12 September 2015/ Revised: 23 December 2015/ Accepted: 2 January 2016/ Published: 6 January 2016 This study follows all ethical practices during writing. Asian Online Journal Publishing Group 


\section{Introduction}

Language is known to one of the most significant aspects in our life as humans. We use language to express our thoughts, emotions, to communicate with others by fulfilling our needs and wants and to make sense of our environment. Human development theorists have stated that language can be defined as verbal, physical, biological and importantly a basic form of communication. As a human, we are nurtured and natured to speak in our mother tongue or the first language since the day we were born. However, challenges take place when we are required to learn a second language which is unknown to us. We may feel uncomfortable, fear as well as anxiety or if we are positive about it, we may feel excited about learning that new language. However, that depends on our perception on how and what we perceive about that second or new language. This is especially critical and important in the life of a student who is a 'foreigner' to this new language, especially English in this day and age. Hence, this was the reason that Hosseini (2013) claims that as a teacher or instructor, in order to explore and get in- tuned with a language leaner's mind, one needs to firstly take the initiative to understand the belief system and the perception of that language student. This is because, in the recent days in language instruction, greater focus has been placed in styles and variables of students as a whole. It is claimed that a learner's beliefs and perception are connected to learning and are currently developing in areas of research in teaching. In most language classrooms, especially in the English lesson, learners usually carry all their personal characteristics and language styles towards learning itself. To an extent, most of the academic researchers concede that in acquiring languages, efficient language learners are inclined to what they are able to anticipate and ways to assess the target language, people who communicate with the target language which indeed play a vital role in the learning process. By just examining the general context of perceptions, beliefs and personal attitudes would not determine any acquisition; those criteria can eventually be the plans or future steps to be taken, where learners play an important role in most of learning. Based on research, social psychologists generally show interest in explanations and investigation which becomes the focal point especially on focusing the concept of a learner's attitude and perception in many fields of study. According to Bailey (2015) attitude is the tendency for a reaction towards a person, idea, object, or situation to be negative or positive. Usually, learners might have a negative or positive attitude concerning the language that they wish to learn or the person they want to communicate with. According to Malallaha (2000) positive attitude towards any examination or test becomes the reason for the learners to obtain better grades in the test. In relation to this, many studies have been conducted to examine the relationship between beliefs and competence in language such as those carried out by Bachman (1990); Malallaha (2000) and Coleman et al. (2003). Furthermore, Gardner (1985) is certain that behaviour together with other emotion based variables are equally crucial abilities for language achievement. This is indeed true because students who have a positive attitude towards learning language, in general, will have internal motivation which will enable them to stay focused and do well in their learning process which in the end does lead to high achievement in their academics especially in language. In a general context, social psychologists have defined perception as the human's recognition and interpretation which is based on the sensory information. Perception is also known as the way we as humans react towards the knowledge gain. Perception is a means in which to receive audio-visual information from the environment and use that information to merge with our environment and make it to something meaningful. Besides that, sensation is commonly referred to the instantaneous, comparatively whole result of stimulation which is stimulated by all five senses. Conversely, perception is better explained as one's decisive understanding of the world and stereotypically includes additional processing of sensory input. It is understandable that both perception and sensation are inseparable aspects which are not on its own, but are known to be a continuous process in human's daily life which allows us as a human to explore the world as a whole (Hosseini, 2013). When a student has a positive perception about language learning, effortlessly there will be a positive attitude in that student to actually learn more about the language, to perform well in the class and in the end to achieve good results or achievement in that language class.

\section{Review of the Related Literature \\ 2.1. IELTS}

The International English Language Testing System or commonly, known as, IELTS, is an international proficiency test developed or standardized for non-native speakers. This test has been recognized since the year 1989 and it is managed by the British Council, IDP: IELTS Australia and Cambridge English language Assessment. At this present day and age, IELTS is known to be one of the important English- language tests worldwide, which includes the TOEFL, TOEIC and OPI. Every year, almost 25,000 students sit for this test and they then will be accepted to enrol in undergraduate or postgraduate study in Australian and British tertiary education together with professional and technical education. IELTS was created on the center of new methods to language teaching and testing. The founders stated that IELTS is based on content, assignment oriented and is importantly original since it relates to real life scenarios. Hence, it is known that IELTS helps one to change the way they live as they look for chances for their education, migration, job opportunities and etc. According to Hosseini (2013) these are the reasons that made IELTS a high stakes test which is indeed tough and has a high demand in measuring English language proficiency. As cited in Hyatt and Brooks (2007) from Criper and Davis (1988) and Hughes et al. (1988) the IELTS was once known as English Language Testing Service (ELTS) and it was implemented to evaluate the prospective of tertiary education learners' language efficiency that was then taken care of by English Proficiency Test Battery (EPTB) in the mid-1960s. Following a few practical administrative problems revolving around the test content it was examined before it could receive approval for research by the ELTS Revision Project to create a new test. Currently its name has been simplified and internationalized to International English Language Testing System (IELTS) which was developed in the year 1989. Between the years of 1989 to 1994, IELTS was monitored based on research evaluations and it was then modified again before being introduced in the year 1995 to replace the three subjectspecific subtests, namely, the Academic Writing and Academic Reading modules as well as the elimination of thematic link that existed between the Writing and Reading modules. Other aspects that were modified in the tests 
were the score of convergence in all modules to nine bands, introduction in checking the consistency of marking, procedure to appeal, procedures of new validation, security and procedures of the computerized administration. Charge and Taylor (1997) stated that the change took place due to the feedback from IELTS administrators and examiners and through research by Clapham (1993) which was into ESP and second language.

Clapham then stated that regardless of the candidates' disciplinary area, the single test did not oppose and can determine the accessibility. With this, many researches were conducted worldwide in order to investigate any issues pertaining to IELTS.

\subsection{Perceptions and Beliefs}

Oxford (2003) stated that it is important to study beliefs in the research of second language learning because successful language students establish understandings into beliefs about the language learning process, potentials and implementation of efficient learning strategies in classroom and the outer environment (Oxford, 2003). Puchta (1999) argues some beliefs may positively affect learning, while other beliefs can impede the learning. Facilitative beliefs may sort out the issues and increase one's motivational drive, while pessimistic beliefs reduce the motivational drive, frustrates the person and may lead the person to be more anxious. Holmes (1992) in Ata (2015) asserts that people who feel positive towards those who use the language would be more effective and have a greater drive to use it. Ata (2015) also cites Johnson \& Johnson (1998) who note that studies on attitude that have been carried out with respect to learning language "range from anxiety about the language and the learning situation to attitudes towards speakers of the second language the country in which it is spoken, the classroom, the teacher, other learners, the nature of language learning, particular elements in the learning activities, tests and beliefs about learning in general". Brown (2000) contends that second language learners of English gain optimism because pessimism leads to reduction of motivational drive. However, Ata (2015) states that pessimism changes, through acquaintance with truth, in which, the learner meets with actual people from other cultures. In contrast to this, many views have shown the drawbacks of having undesirable attitudes towards the learning of a second language. Such views can be seen in Gardner and Lambert (1972) where the students who perceive L2 negatively are those who don't use the effort to speak for acquiring L2 aspects, apart from being uncongenial and adopting the transfer of L2. Littlewood (1983) agrees with this, asserting that such attitudes obstruct the learners' learning process, causing them to lose interest and prevent them from gaining new knowledge in learning the second language. Ata (2015) stated that one will not be able to obtain significant progress in the language learning process if a person has negative attitudes on the targeted language and towards others who uses that language. Truitt (1995) on the other hand quoted that cultural background and previous experiences vary and influence the students' beliefs and attitudes about language learning. Hence, it can be debated that positive and negative attitude happens due to reasons rather than being unintentional. In a study by Malallaha (2000) the attitudes of Kuwaiti students on English were investigated and the study showed that these students have positive attitudes on English language. Apart from that, the students' proficiency and their attitude in English language were also positively related. Hence, it can be concluded that there will be an effect on students' performance on language test despite having positive or negative attitudes about it Ata (2015). Studies carried out on the perception of IELTS higher education in Australia, UK, and China by Coleman et al. (2003) found that some students felt that the IELTS course did not improve their English because it was form of training that would help them to do well in the exam. Thus, students are not intrinsically motivated to learn English through the IELTS course but rather they are forced to go through with the process because it is the only way for them to get into university. When a student is forced into a situation they will not be able to fully learn from it because the knowledge that they acquire is meaningless to them. Other studies carried out on the IELTS test found in Ata (2015) include Merrylees (2003) study on two user groups of IELTS. One group consists of candidates who took IELTS for the purpose of immigration and the other group took the test with the purpose of secondary education. With the entry of both groups, Merrylees (2003) believed that there is a need to investigate and analyze the way the both groups do on the test based on their race, age, sex and any other variables instead of making a broad comparative analysis. Ata (2015) also found Arab-speaking students with a poor lexical or specific cultural knowledge of English can cause several negative interferences. His study produced a significant proposition - one which infers that it is important for IELTS to prepare the materials inclusive of texts and tasks that can enhance the collective and theoretical acculturation aspect of the students. Hence, according to Hosseini (2013) based on the students mentioned above, and the impact which includes perception, attitude, and belief towards learners' performance, it is indeed important to assess and evaluate the attitudes and perception of IELTS candidates. Therefore, this study is conducted in order to investigate the correlation of learners' perception to the IELTS test prior to and after they sit for it.

\section{Methodology}

A standardized IELTS test that has 25 items on listening comprehension, 35 items on reading comprehension and 2 items on writing were given to a group of 40 IELTS students from Kolej MARA Banting from various engineering classes.

\subsection{Instruments}

This study involved the use of three instruments in order to collect the data needed.

1. A standard IELTS (general module, 2007)

2. Questionnaire on perception that was created and validated by Ransom et al. (2005) based on survey regarding International ESL students' attitudes and outlook on English language necessities of learning and support from the University of Melbourne.

\subsection{Data Analysis}

Three levels of analysis were carried out:

1. A normality test comparing the IELT's learners' perceptions prior to and after taking the test. 
2. A paired samples t-test comparing the IELT's learners' perceptions prior to and after taking the test

\subsection{Procedure}

The participants sat for IELTS test and based on the test's results, 20 subjects were randomly selected for this study. The candidates will firstly answer the questionnaire on their perceptions. Next they will be given the IELTS general module test and finally they will receive the same questionnaires on their perceptions. At the end of this study, the learners' responses to the questionnaire on perception before and after the IELTS will be compared in order to identify any significant difference in the perceptions before and after taking the test as well as the correlation in their response.

\section{Outcomes and Findings}

To test any sets of data parametrically for analysis, assumptions on interval data, subject independence, normality distribution and variances of homogeneity are crucial elements to be analysed. The data consisting of independent subjects were measured on an interval scale. The assumption for a normal distribution was tested empirically over their standard deviation through skewness and kurtosis ratios. As an outcome of the result, the table shows that the pre-test is not significant but post-test is significant. We can conclude that the pre-test data is normally distributed but post-test is not.

As displayed in Table 1 the mean score of the students on the posttest of perception $(\mathrm{M}=3.667)$ shows improvement over the mean score on the pretest $(M=3.344)$.

Table-1. Pre and Post Test Mean and Standard Deviation

\begin{tabular}{l|c|r|r|r}
\hline \multicolumn{5}{c}{ Paired Samples Statistics } \\
\hline & Mean & N & Std. Deviation & Std. Error Mean \\
\hline Pretest & 3.3444 & 20 & .50456 & .11282 \\
\hline Posttest & 3.6667 & 20 & .33817 & .07562 \\
\hline
\end{tabular}

Table-2. Paired Samples T- Test

\begin{tabular}{|c|c|c|c|c|c|c|c|c|}
\hline \multicolumn{9}{|c|}{ Paired Samples Test } \\
\hline & \multicolumn{4}{|c|}{ Paired Differences } & & & & \\
\hline & \multirow[t]{2}{*}{ Mean } & \multirow{2}{*}{$\begin{array}{l}\text { Std. } \\
\text { Deviation }\end{array}$} & \multirow{2}{*}{$\begin{array}{l}\text { Std. Error } \\
\text { Mean }\end{array}$} & \multicolumn{2}{|c|}{ 95\% Confidence Interval of the Difference } & \multirow[t]{2}{*}{$\mathrm{T}$} & \multirow[t]{2}{*}{ df } & \multirow{2}{*}{$\begin{array}{l}\text { Sig. (2- } \\
\text { tailed) }\end{array}$} \\
\hline & & & & Lower & Upper & & & \\
\hline $\begin{array}{l}\text { Pair } 1 \\
\text { pretest - } \\
\text { posttest }\end{array}$ & -.32222 & .49151 & .10991 & -.55226 & -.09219 & -2.932 & 19 & .009 \\
\hline
\end{tabular}

Source: Adapted from Hosseini (2013)

The results of the paired samples t-test provide evidence for a significant and meaningful difference among the mean scores of the candidates on the pre-test and post-test of perception $(\mathrm{t}(19=-2.932, \mathrm{P}=0.009<.05$ it does represent a large effect size). Based on these results it was concluded that there are significant difference between the candidates' perception before and after taking the IELTS test.

The following discrete data plot illustrates the mean scores of the subjects' perceptions before and after the IELTS test.

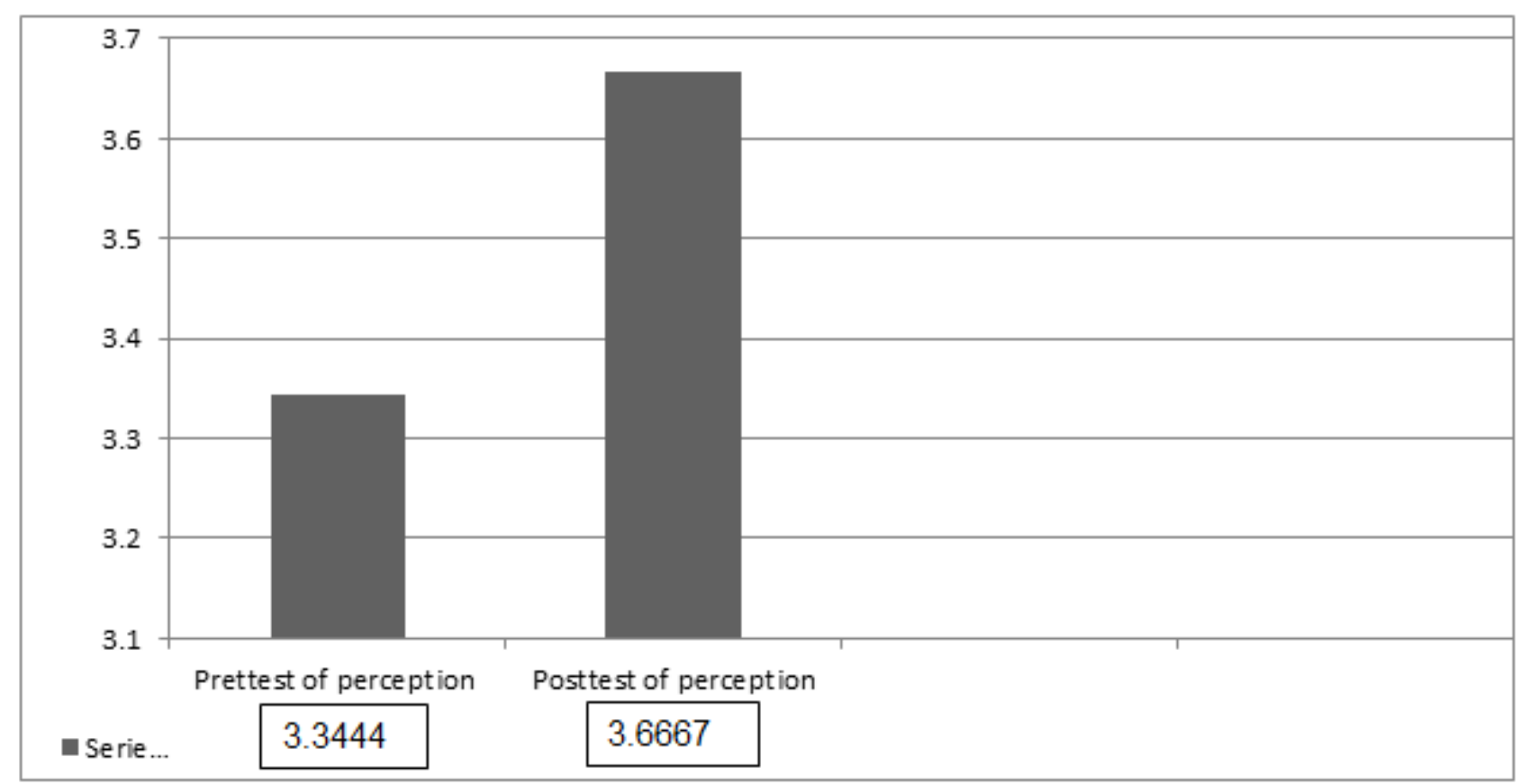

Figure-1. Average scores on perception of IELTS, pre-test and post-test

\section{Findings}

The results showed that there is a significant difference in IELTS learners' perceptions prior to and after the IELTS test. The result indicates candidates' perceptions towards the test are affected in the real situation of test taking. The result of this study is agreeable to the past researches from Cook (1999); Griffith and Parr (2001); 
Modiano (2001); Sherry et al. (2004). Hence, based from this study, it is agreeable that students who participate in high stake examinations do experience great level in stress and are more anxious and in the end effect their test performance. Skehan (1998) stated that students' perceptions towards test and their expectations from the test are appositively correlated with their assumption on learning either for authentic or original. Dornyei and Skehan (2003) stated assumption and perceptions of a person in language learning and teaching process is also affected by the students' individual differences. The researchers also stated that the Iranian students take part in cramming courses which is targeted to prepare students for the high state examinations such as IELTS and TOEFL. Hosseini (2013) stated that this type of courses has mock exams in order to prepare the students with an understanding prior knowledge of the students and the degree they can do in actual test. Hence, the result shows that there is a high difference when the students who participated in this research do look forward for the similar experience as their perceptions about IELTS exam prior to and after taking the test. Based on the comparison in mean scores during the pretest and the posttest of perception results it was found that students who participated in the study experienced greater and a more positive perception of the IELTS after taking the test. This is due to the nature of the test itself which positively impact the students. The result of this study is agreed on by many researchers. For instance, Read and Hayes (2003) did a study to investigate the correlation of IELTS preparation programs with the candidates' performance on the actual IELTS test in New Zealand. The results showed that candidates who went through the preparation programs had substantial difference in performance compared to candidates who did not go through the preparation program.

\section{Conclusion}

The objective of the study was to examine the link among learners' perception prior to and after taking the IELTS test. To carry out the research 20 IELTS subjects were chosen. Prior to and after the IELTS test, the participants were given questionnaires to assess their perceptions. After collecting the mandatory data, a paired samples t-test was conducted to examine any major significance among the perception of the IELTS learners prior to and after taking the test. The findings showed, there was a significant improvement upon completing the rest. It is hoped that the study will benefit all IELTS stakeholders especially those candidates who are planning to take the test, educational organizations who are overseeing IELTS preparatory programs, educators who aspire to train candidates in such programs and administer the test. There are a few recommendations that could be carried out to further probe issues relevant towards IELTS in Malaysia which includes:

1. Research which includes IELTS Reading and Listening tests.

2. Research involving test preparatory methods and analysis of the intellectual processes of IELTS test takers

3. Lastly, continuous research should be conducted to question the development in writing IELTS test components.

Importantly the researchers of this study believe perceptions do play an important and vital role in the attitude of a person. As for this study, when the students have positive perception towards their studies (in general) and IELTS test (specifically), they will have the internal motivation and will put the effort to achieve well in their academics. However, if the students choose to be negative minded, they may end up failing or not succeeding in their academics. This attitude definitely will be carried out as the students move on to the next phase of life. Hence, the researchers conclude that, positive perception does lead to optimistic attitude will bring success to one's life, while the negative perception which leads to pessimistic attitude will be an obstacle in one's life to succeed.

\section{References}

Ata, A., 2015. Knowledge, education, and attitudes of international students to IELTS: A case of Australia. Journal of International Students, 5(4): 2015-2015.

Bachman, L., 1990. Fundamental considerations in language testing. Oxford: Oxford University Press.

Bailey, C.D., 2015. Psychopathy, academic accountants' attitudes toward unethical research practices, and publication success. Accounting Review, 90(4): 1307-1332.

Brown, D.H., 2000. Principles of language learning and teaching. 4th Edn., White Plains, NY: Pearson Education.

Charge, N. and L. Taylor, 1997. Recent developments in IELTS. English Language Teaching Journal, 51(4): 374-380.

Clapham, C., 1993. Is ESP testing justified? In D. Douglas \& C. Chapelle (Eds.), A new decade of language testing research. Alexandria, VA: TESOL. pp: 257-271. Clapham, C. (1995). What makes an ESP reading test appropriate for its candidates? In A. Cumming \& R. Berwick (Eds.), Validation in language testing. Clevedon, UK: Multilingual Matters Ltd. pp: 171-193.

Coleman, D., S. Strafield and A. Hagan, 2003. The attitudes of IELTS stakeholders: Student and staff apperception of IELTS in Australian, UK, and Chinese tertiary institutions. IELTS Australia Research, 5: 20-34.

Cook, V., 1999. Going beyond the native speaker in language teaching. TESOL Quarterly, 33(2): 185-209.

Criper, C. and A. Davis, 1988. ELTS validation project report: Research Report 1(i). The British Council/University of Cambridge Local Examinations Syndicate.

Dornyei, Z. and P. Skehan, 2003. Individual differences in second language learning. In C.J. Doughty \& M. H. Long (Eds.), The handbook of second language acquisition. USA: Blackwell Publishing Ltd. pp: 589-630.

Gardner, R.C., 1985. Social psychology and second language learning: The role of attitudes and motivation. London: Edward Arnold Publishers.

Gardner, R.C. and W.E. Lambert, 1972. Attitudes and motivation in second language learning. Rowley, Massachusetts: Newbury House.

Griffith, C. and J.M. Parr, 2001. Language-learning strategies: Theory and practice. ELT Journal, 55(3): 247-254.

Holmes, J., 1992. An introduction to sociolinguistics. New York: Longman Group UK Limited.

Hosseini, S.B., 2013. A study on the perception of Iranian candidates towards the general IELTS test. International Journal on New Trends in Education and Their Implications, 4(4): 184-196.

Hughes, A., D. Porter and C. Weir, 1988. ELTS validation project report: Proceedings of a Conference Held to Consider the ELTS Validation Project Report - Research Report 1(iii). The British Council/University of Cambridge Local Examinations Syndicate.

Hyatt, D. and G. Brooks, 2007. Investigating stakeholders perceptions of IELTS as an entry requirement for higher education in the UK. IELTS Research Reports, 10: 1-50.

Littlewood, W., 1983. Communicative language teaching: An introduction. Cambridge: Cambridge University Press.

Malallaha, S., 2000. English in an Arabic environment: Current attitudes to English among Kuwait university students. International Journal of Bilingual Education and Bilingualism, 3(1): 19-43.

Merrylees, B., 2003. An impact study of two IELTS user groups: Candidates who sit for the immigration purposes and candidates who sit for secondary education purposes. IELTS Australia Research, 4(1): 27-39.

Modiano, M., 2001. Ideology and the ELT practitioner. International Journal of Applied Linguistics, 11(2): 159-173. 
Oxford, R., 2003. Language learning styles and strategies: Concepts and relationships. International Review of Applied Linguistics in Language Teaching, 41(4): 271-278.

Puchta, J., 1999. Beyond materials, techniques, and linguistic analysis: The role of motivation, beliefs, and identity. Plenary Paper. 33rd International IATEFL Annual Conference, Edinburgh.

Ransom, L., W. Larcombe and C. Baik, 2005. English language needs and support: International-esl students' perceptions and expectations. Language and learning skills unit, the university of melbourne, victoria, 3010, australia. Available from http://www.services.unimelb.edu.au/llsu/ [Accessed October, 8, 2015].

Read, J. and B. Hayes, 2003. The impact of IELTS on preparation for academic study in New Zealand. IELTS Research Reports, 4. IELTS Australia, Canberra.

Sherry, C., R. Bhat, B. Beaver and A. Ling, 2004. Students as customers: The expectations and perceptions of local and international students. Paper Presented to the Higher Education Research and Development Conference, Curtin University, 2004.

Skehan, P., 1998. A cognitive approach to language learning. Oxford: Oxford University Press.

Truitt, H., 1995. Beliefs about language learning: A study of Korean University students learning English. Texas Papers in Foreign Language Education, 2(1): 1-16.

Appendix-1. Questionnaire on the perception of language learning

\begin{tabular}{|c|c|c|c|c|c|c|}
\hline No. & $\begin{array}{l}\text { Item } \\
\end{array}$ & 1 & 2 & 3 & 4 & 5 \\
\hline 1 & $\begin{array}{l}\text { How do you rate your current English } \\
\text { language skills? }\end{array}$ & $\begin{array}{c}\text { Low } \\
\text { Intermediate }\end{array}$ & Intermediate & High & Very High & $\begin{array}{c}\text { Native } \\
\text { Proficiency }\end{array}$ \\
\hline \multirow[t]{4}{*}{2} & $\begin{array}{l}\text { How MANY HOURS PER WEEK do } \\
\text { you plan to }\end{array}$ & None & 1 to 2 & 3 to 4 & 5 to 6 & $7+$ \\
\hline & $\begin{array}{c}\text { spend outside your classes further } \\
\text { developing }\end{array}$ & & & & & \\
\hline & $\begin{array}{l}\text { your English language skills this year } \\
\text { (other than }\end{array}$ & & & & & \\
\hline & by social conversation)? & & & & & \\
\hline 3 & $\begin{array}{l}\text { Which ONE of the four key English } \\
\text { language skills } \\
\text { do you think is most important for } \\
\text { getting high } \\
\text { marks in your exam? (select only one) }\end{array}$ & Writing & Reading & Speaking & Listening & All skills \\
\hline \multirow[t]{2}{*}{4} & $\begin{array}{l}\text { Which ONE of the four key English } \\
\text { language skills }\end{array}$ & & & & & \\
\hline & $\begin{array}{l}\text { do you think you need to improve } \\
\text { most? (select only one) }\end{array}$ & Writing & Reading & Speaking & Listening & All skills \\
\hline \multirow[t]{2}{*}{5} & $\begin{array}{l}\text { What is the lowest mark that you would } \\
\text { be }\end{array}$ & & & & & \\
\hline & happy with for the test? & 4 to 5 & 5 to 6 & 6 to 7 & 7 to 8 & 8 to 9 \\
\hline \multirow[t]{2}{*}{6} & $\begin{array}{c}\text { How important is it for you to improve } \\
\text { your }\end{array}$ & & & & & \\
\hline & CONVERSATIONAL English? & Not & A little & Somewhat & Much & Very \\
\hline 7 & $\begin{array}{c}\text { How important is it for you to improve } \\
\text { your } \\
\text { ACADEMIC English? }\end{array}$ & Not & A little & Somewhat & Much & Very \\
\hline \multirow[t]{3}{*}{8} & $\begin{array}{l}\text { For your major, do you think English } \\
\text { language }\end{array}$ & & & & & \\
\hline & $\begin{array}{l}\text { proficiency will be important for } \\
\text { getting a better admission overseas? }\end{array}$ & & & & & \\
\hline & & Not & A little & Somewhat & Much & Very \\
\hline 9 & $\begin{array}{l}\text { How much do you think the results of } \\
\text { the exam will affect your future life? }\end{array}$ & Not & A little & Somewhat & Much & Very \\
\hline
\end{tabular}

Source: Ransom et al. (2005) based on a survey of international ESL students' perceptions and expectations of English language learning needs and support at the University of Melbourne 